\title{
Menekan Angka Kesenjangan Sosial di Indonesia melalui Sustainable Development Goals Perspektif Ekonomi Islam
}

\author{
Abdurrahman Hakim \\ Institut Agama Islam Negeri Tulugagung \\ Email :Cakman1996@gmail.com
}

\begin{abstract}
This paper aims to describe solutions to reduce social inequality in Indonesia. The use of Islamic economic principles is offered by the author because it has the appropriate value of justice and equity to solve problems arising from sustainable development. Even though it is oriented towards fulfilling the future, it turns out that the concept of sustainable development has not been able to become the solution expected by the community, especially those in remote and border areas. The research method used in this paper is library research. Sources of data use secondary data in the form of journals, books, newspapers, mass media, and online media. The results of this study provide recommendations to the public and government to make use of natural resources based on the basic principles of Islamic economics, namely ownership of Allah alone, freedom to utilize resources, and balance.
\end{abstract}

Keywords : social inequality, islamic economic, sustainable development goals.

Abstrak : Tulisan ini bertujuan untuk mendiskripsikan solusi guna menekan angka kesenjangan sosial di Indonesia. Penggunaan prinsip-prinsip ekonomi Islam ditawarkan oleh penulis karena memiliki nilai keadilan dan pemerataan yang sesuai untuk memecahkan permasalahan yang timbul dari pembangunan berkelanjutan. Meski berorientasi pada pemenuhan masa depan, terrnyata konsep pembangunan berkelanjutan belum mampu menjadi solusi yang diharapkan masyarakat terutama yang berada di daerah terpencil dan perbatasan. Metode penelitian yang digunakan dalam tulisan ini adalah penelitian kualitatif dengan jenis penelitian pustaka. Sumber data menggunakan data-data sekunder berupa jurnal, buku, surat kabar, media massa dan media online. Hasil penelitian ini memberi rekomendasi kepada masyarakat dan pemerintah agar memanfaatakan sumber daya alam berdasarkan prinsip-prinsip dasar ekonomi Islam yaitu kepemilikan hanya miliki Allah, kebebasan untuk memanfaatkan sumber daya, dan keseimbangan.

Kata Kunci : kesenjangan sosial, ekonomi islam, pembangunan berkelanjutan

\section{A. Pendahuluan}

Gagasan pembangunan berkelanjutan (Sustainable Development Goals) sebenarnya merupakan konsep lama. Persoalan polusi yang disebabkan oleh pembangunan indsustri pada tahun 1970 merupakan salah satu alasan diangkatnya konsep tersebut pada Konferensi Stockholm tahun 1972 di Nairobi. Konferensi Stockhlom bertujuan untuk menyelesaikan persoalan lingkungan fisik global baik di negara maju maupun di negara berkembang. ${ }^{1}$

Setelah itu, topik Pembangunan Berkelanjutan diangkat sebagai salah satu isu global pada Konferensi Tingakat Tinggi (KTT) PBB tahun 1992 di Rio de Jenairo. Hasilnya, hampir seluruh negara menggunakan selogan Pembangunan Berkelanjutan sebagai jargon pembangunan pasca berakhirnya konsep Millennum Development Goals (MDGs) pada tahun $2015 .^{2}$

Gagasan Pembangunan Berkelanjutan merupakan inovasi dan trobosan pembangunan yang awalnya hanya berjangka pendek menjadi pembangunan berjangka panjang. Definisi pembangunan berkelanjutan yang paling umum adalah pembangunan dengan orientasi pemenuhan kebutuhan generasi saat ini dengan mengoptimalkan penggunaan Sumber Daya

${ }^{1}$ Mira Rosana, "Kebijakan Pembangunan Berkelanjutan Yang Berwawasan Lingkungan Di Indonesia," KELOLA Jurnal Ilmu Sosial 1, no. 1 (2018): 148-163. h. 151-152

${ }^{2}$ Akhmad Fauzi and Alex Oxtavianus, "The Measurement of Sustainable Development in Indonesia," Jurnal Ekonomi Pembangunan: Kajian Masalah Ekonomi dan Pembangunan 15, no. 1 (2014): 68. h. 69-76. 
Alam tanpa mengorbankan pemenuhan kebutuhan generasi yang akan datang. Dimensi pembangunan berkelanjutan mencakup tiga hal, yaitu; ekonomi, sosial dan lingkungan. ${ }^{3}$

Ada tiga (3) karakter utama jika suatu pembangunan agar bisa dikatakan sebagai Pembangunan Berkelanjutan, yaitu; 1. Penggunaan Sumber Daya Alam yang optimal, 2. Pembagunan tidak menyebabkan terjadinya polusi udara dan dampak negatif pada lingkungan lainnya, 3. Adanya upaya untuk memperbarui pemakaian sumbar daya alam. ${ }^{4}$ Tiga alasan tersebut merupakan solusi agar sumber daya alam yang dipakai tidak habis hanya pada satu generasi saja. Meski pada nyatanya, banyak sumber daya alam yang tidak dapat diperbarui secara cepat, seperti minyak bumi, maka solusi penggunaan harus menggunakan alternatif sumber daya alam yang memiliki sifat atau kegunaan yang sama. Pada dasarnya, nilai-nilai penting dari pembangunan berkelanjutan harus memiliki gagasan yang progresif pada aspek ekonomi, sosial dan keberlangsungan lingkungan.

Pembangunan berkelanjutan bukan hanya gagasan pembangunan yang dipelopori oleh negara-negara Eropa dan Amerika. Islam sebagai salah satu agama yang membawa konsep pembangunan berwawasan lingkungan juga memiliki aturan-aturan mengenai pemanfaatan lingkungan dalam al-Qur'an. Al-Qur'an telah memprediksi bahwa setiap tingkah laku manusia yang berhubungan dengan alam sebagai pengrusakan. Sebagaimana firman Allah dalam al-Qur'an: "Telah nampak kerusakan di darat dan di laut disebabkan karena perbuatan tangan manusi, supaya Allah merasakan kepada mereka sebagian dari (akibat) perbuatan mereka, agar mereka kembali (ke jalan yang benar)."

Melalui konsep pembangunan yang berkelanjutan, hak-hak generasi berikutnya memang sudah terjamin. Namun, konsep pembangunan terebut belum mampu menekan angka kesenjangan sosial di Indonesia. Artinya, masalah pembangunan masih terpusat pada satu wilayah dan menguntungkan segelintir orang saja, sehingga kesejahteraan yang menjadi tujuan pembangunan belum bisa dirasakan oleh semua elemen masyarakat.

Tabel 1. Kesenjangan Sosial Menurut Data Kepulauan di Indonesia 2019

\begin{tabular}{|c|c|l|l|}
\hline No & Pulau & \multicolumn{1}{|c|}{ Persentase } & \multicolumn{1}{|c|}{ Jumlah Penduduk } \\
\hline 1 & Jawa & Desa: $12.81 \%$, Kota: $6.82 \%$ & 152.449 .900 Jiwa \\
\hline 2 & Sumatera & Desa: $11.66 \%$, Kota: $8.65 \%$ & 59.337 .100 Jiwa \\
\hline 3 & Kalimantan & Desa: $7.60 \%$, Kota: $4.33 \%$ & 16.769 .700 Jiwa \\
\hline 4 & Bali-NTB-NTT & Desa: $17.77 \%$, Kota: $9.18 \%$ & 15.047 .800 Jiwa \\
\hline 5 & Papua & Desa: $29.15 \%$, Kota: $5.03 \%$ & 4.417 .200 Jiwa \\
\hline 6 & Sulawesi & Desa: $13.68 \%$, Kota: $5.83 \%$ & 19.934 .000 Jiwa \\
\hline
\end{tabular}

Sumber: Bappenas ${ }^{6}$

Data tersebut menunjukkan bahwa persentase kemiskinan di Papua sangat tinggi padahal jumlah penduduknya sangat sedikit. Berbading terbalik dengan rendahnya kemiskinan di Jawa dan Sumatera dengan penduduk yang sangat tinggi. Data tersebut juga membuktikan bahwa pertumbuhan ekonomi masih berpusat di Jawa dan Sumatera.

\footnotetext{
${ }^{3}$ Khusnul Ashar Niken Pratiwi, Dwi Budi Santosa, "Analisis Implementasi Pembangunan Berkelanjutan Di Jawa Timur," Jiep 18, no. 1 (2018): 1-16. h. 2-3

${ }^{4}$ A.H. Rahadian, "Strategi Pembangunan Berkelanjutan," Prosiding Seminar STIAMI III, no. 01 (2016): 46-56, file:///C:/Users/USER/Downloads/strategi-pembangunan-berkelanjutan (1).pdf.

${ }^{5}$ Departemen Agama RI, Al-Quran Dan Terjemahnya (Jakarta: Gema Insani press, 2003). h. 807

${ }^{6}$ BPS, Proyeksi Penduduk Indonesia 2010-2035, Bulletin of Experimental Biology and Medicine, vol. 90 (Jakarta: Bada Pusat Statistik, 2013). h. 2- 30
} 
Standar untuk mengukur pertumbuhan ekonomi di Indonesia masih menggunakan data secara umum. PDB merupakan ukuran yang baik untuk menentukan kesejahteraan ekonomi pada suatu negara. Meningkatnya nilai PDB pada suatu negara akan menarik investor untuk berinvestasi. Tingkat investasi yang semakin tinggi akan meningkatkan harga saham di pasar modal. $^{7}$

Meski, data yang dihasilkan melalui perhitungan tersebut selalu positif dan menunjukkan pertumbuhan ekonomi yang sangat baik. Namun, kenyataanya masih jumlah penduduk miskin di Indonesia masih tergolong tinggi.

Kelemahan perhitungan menggunakan PDB ialah hanya bisa menghasilkan data umum tingkat nasional. Ketika data yang sudah dikeluarkan diterjemahkan ke dalam pendapatan perkapit penduduk, maka jumlah tersebut akan merata. Perhitungan tersebut tidak mampu merepresentasikan pendapatan setiap penduduk secara benar. Pada tahun 2018, kesenjangan sosial di Indonesia masih tergolong sangat tinggi. Himpunan Pengusaha Muda Indonesia atau HIPMI menyebutkan bahwa $1 \%$ masyarakat Indonesia menguasai 50,3\% aset atau kekayaan nasional. ${ }^{8}$ Artinya, jika data tersebut diakmulasikan untuk dihitung dengan pendekatan PDB, maka angka 50.3\% akan dianggap sebagai kekayaan seluruh masyarakat Indonesia.

\section{B. Metode Penelitian}

Penelitian ini menggunakan pendekatan kualitatif dengan jenis penelitian pustaka. Sumber data yang digunakan adalah data-data berupa data sekunder diantaranya buku-buku, jurnal, enslikopedia, media online, surat kabar dan sebagainya. ${ }^{9}$ Penelitian pustaka digunakan karena mempertimbangan waktu pelaksanaan program oleh pemerintah yang memiliki periode yang cukup panjang. Hasil penelitian kemudian dianalisi menggunakan teori-teori Ekonomi Islam dan teori pembangunan berkelanjutan.

\section{Hasil dan Pembahasan}

\section{Pengertian Ekonomi Islam}

Dalam Islam, ekomomi atau iqtishad memiliki dua arti kata yaitu keadilan (equality balanced) dan keseimbangan (equilibrium). ${ }^{10}$ Dawam Raharjo mendefinisikan ekonomi Islam sebagai ilmu dan sistem. Pertama, ekonomi Islam adalah ilmu yang mempelajari tentang perekonomian yang berlandaskan ajaran dan syariat Islam. Kedua, ekonomi Islam adalah sistem perkonomian yang mengatur kegitan ekonomi pada negara dan masyarakat berdasarkan metode tertentu. ${ }^{11}$ Sama halnya dengan diskursus lainnya yang didasarkan pada

\footnotetext{
${ }^{7}$ Habib Muhammad Husnul, Raden Rustam Hidayat, and Sri Sulasmiyati, "Analisis Pengaruh Inflasi, Kurs (IDR/USD), Produk Domestik Bruto Dan Harga Emas Dunia Terhadap Indeks Harga Saham Gabungan,” Jurnal $\begin{array}{llllll}\text { Administrasi } & \text { Bisnis } & 53, & \text { no. } & 1 & \text { (2017): }\end{array}$ http://administrasibisnis.studentjournal.ub.ac.id/index.php/jab/article/view/2183.

${ }^{8}$ Zulfi Suhendra, "HIPMI Sebut 1\% Orang Kaya RI Kuasai 50\% Kekayaan Nasional," DetikFinance, last modified 2018, accessed June 19, 2020, https:/finance.detik.com/berita-ekonomi-bisnis/d-4056625/hipmi-sebut1-orang-kaya-ri-kuasai-50-kekayaan-nasional?_ga=2.175454443.837156960.1576976882430614702.1562817330.

${ }^{9}$ Zainuddin Ali, Metodologi Penelitian Hukum (Jakarta: Sinar Grafika, 2011). h. 55

${ }^{10}$ Ika Yuni Fauzia and Abdul Kadir Riyadi, Prinsip-Prinsip Dasar Ekonomi Islam (Jakarta: Kencana, 2014). h. 3

${ }^{11}$ M.Dawam Rahardjo, Islam Dan Tansformasi Sosial Ekonomi (Jakarta: LSAF, 2012). h. 4
} 
ajaran Islam, ekonomi Islam merupakan implementasi dari konsep perkonomian yang bersumber dari al-Qur'an, al-Hadits, Ijma', dan Qiyas. ${ }^{12}$

\section{Konsep Pembangunan Berkelanjutan}

Pembangunan berkelanjutan atau yang dikenal dengan istilah sustainable deveopment goals (SDGs) merupakan pembangunan yang berorientasi pada pemenuhan kebutuhan saat ini dan masa yang akan datang. Fokusnya meliputi sektor ekonomi, sosial, dan lingkungan. ${ }^{13}$ Berdasarkan konsep tersebut, makan pembanguna di Indonesia harus tetap berjalan dengan memperhatikan keberlangsungan ekosistem, sumber daya alam, kondisi sosial dan politik masyarakat, serta bertujuan untuk membangun perekonomian masyarakat.

Pembangunan berkelanjutan merupakan gagasan yang muncul akibat adanya dua tuntutan bagi manusia dalam menjalani kehidupan. Pertama, sebagai makhluk hidup, manusia harus memenuhi kebutuhannya yang bisa dieroleh dan dikelola dari alam. Kedua, sumber daya alam yang ada tidak semua meruakan sumber daya alam yang dapat diperbaharui, oleh karenanya perlu ada pembatasan, efesiensi, dan pembaharuan dalam pemakaian serta berusaha untuk menemukan sumber daya alternatif. ${ }^{14}$

\section{Pembangunan Berkelanjutan Berdasarkan Prinsip-prinsip Ekonomi Islam}

Kesenjangan sosial merupakan masalah utama pembangunan ekonomi di negara-negara berkembang. Kesenjangan muncul akibat pembangunan ekonomi hanya memprioritaskan wilayah tertentu saja. Jika mengacu pada prinsip ekonomi Islam yang mengedepankan pemerataan dan keseimbangan, maka pembangunan di Indonesia yang hanya memprioritaskan daerah Jawa dan Sumatera jelas berentangan dengan prisip-prinsip tersebut. Dampaknya, kesejahteraan yang diukur melalui pendapatan perkapita penduduk sangat jauh berbeda antara satu wilayah dengan wilayah yang lain yang cenderung diabaikan.

Masterplan Ekonomi Islam di Indonesia pada tahun 2019-2024 memiliki landasan pembangunan ekonomi yang berkeadilan dan berkelanjutan. Konsep ekonomi Islam diharapkan mampu membawa kemajuan secara inklusif, merata, berkelanjutan, dan tahan terhadap krisis. Tujuannya, pada tahun 2024 Indonesia sudah mampu membangun perekonomian yang mandiri, kokoh, makmur dan madani. Pembangunan berkeanjutan di Indonesia harusnya mengacu pada prinsip-prinsip dasar ekonomi Islam untuk mendorong terwujudnya pemerataan tersebut. Sadono Sukirno bahwa ada empat upaya yang bisa dilakukan untuk menekan angka kesenjangan sosial di Indonesia: ${ }^{15}$

Pertama, Konektifitas dan Infrastrukur untuk mencapai kesejahteraan masyarakat yang merata, perlu adanya kebijakan pendistribusian aspek ekonomi secara adil. Jika melihat kondisi geografis Indonesia yang sangat luas dan dipisahkan oleh laut. Maka, infrastruktur baik di darat, laut dan udara harus dibangun dengan baik untuk mendorong terjalinnya konektivitas ekonomi antar daerah di Indonesia. Infrastruktur adalah bentuk kerjasama antara pemerintah dengan Bank Indonesia yang diprioritaskan untuk menunjang peningkatan kapasitas produksi dan kegiatan perekonomian secara luas. ${ }^{16}$ Melihat tingginya angka kesenjangan sosial antara daerah di Indonesia, dengan pertumbuhan ekonomi yang membaik,

\footnotetext{
${ }^{12}$ Madziatul Churiyah, Mengenal Ekonomi Islam (Surabaya: Surya Pena Publishing, 2014). h. 14

${ }^{13}$ Fauzi and Oxtavianus, "The Measurement of Sustainable Development in Indonesia." h. 42-52

${ }^{14}$ Nur Listiawati, "Pelaksanaan Pendidikan Untuk Pembangunan Berkelanjutan Oleh Beberapa Lembaga," Jurnal Pendidikan dan Kebudayaan 19, no. 3 (2013): 430.

${ }^{15}$ Sadono Sukirno, Makroekonomi Teori Pengantar (Jakarta: Raja Grafindo Persada, 2015). h. 438-441

${ }^{16}$ Agung Eko Purwana, "Pembangunan Nasional Dalam Perspektif Ekonomi Islam," Justitia Islamica 10, no. 1 (2013). h. 3
} 
maka dapat kita pahami bahwa infrastruktur yang dibangun hanya terkonsentrasi di berbagai daerah saja, seperti Jawa dan Sumatera. Pembangunan infrastruktur yang dilakukan secara merata memiliki efektivitas yang baik dalam menunjang meningkatnya pendapatan masyarakat. Sebagai bukti, sebelum digagasnya pembangunan nasional yang digagas oleh Jokowi-JK dan pembangunan hanya terpusat di Jawa dan Sumatera, maka taraf ekonomi dan kesejahteraan di dua pulau tersebut meningkat. ${ }^{17} \mathrm{Hal}$ ini bisa menjadi dasar evaluasi bagi pemerintah, bahwa pemerataan pembangunan akan mendorong kualitas perekonomian yang merata dan menurunnya angka kesenjangan antar pulau di Indonesia. Dalam konsep Islam, pembangunan infrastruktur merupakan upaya meningkatkan perekonomian umat yang sangat penting. Integritas wilayah dalam Islam adalah hal yang menjadi pesan utama nabi pada gubernur-gubernur yang sudah dilantik. Dalam konsep ekonomi Islam, keuangan negara juga diprioritaskan untuk membangun fasilitas umum seperti jalan, pelabuhan, terminal, stasiun, panti dan sekolah. ${ }^{18}$

Kedua, pendidikan. Antara pertumbuhan ekonomi dan pembangunan berkelanjutan memiliki korelasi dan hubungan timbal balik. Pembangunan ekonomi merupakan prasyarat untuk membangun sumber daya manusia dan sumber daya manusia adalah syarat penting untuk membangun perekonomian yang merata. Jika sektor ekonomi sudah didukung dengan kualitas sumber daya manusia yang memadai, maka perekonomian akan mencapai keseimbangan, produktivitas yang tinggi, pemerataan dan pemberdayaan. ${ }^{19}$ Pembangunan sumber daya manusia tentunya harus merata. Sebagai negara yang besar dan memiliki sumber daya alam yang memadai di semua kepualauan di Indonesia. Maka, pembanguan sumber daya manusia sebagai subjek dan pelaku ekonomi juga harus merata. Umumnya pembangunan berkelanjutan di Indonesia melalui sistem pendidikan nasional. Aspek Pendidikan adalah hal yang penting dalam menyongsong strategi pembangunan berkelanjutan. Pendidikan Pembangunan Berkelanjutan atau yang dikenal dengan Educations Sustanable Development merupakan alat pendidikan atau strategi pembelajaran untuk membentuk karakter siswa agar menyadari ketergantungan mereka terhadap unit ekologis. ${ }^{20}$ Educations Sustanable Development berorientasi pada misi untuk membangun sistem pendidikan kemasyarakatan dan penguatan ekonomi mayarakat ${ }^{21}$, pendidikan yang untuk memanfaatakan sumber daya secara optimal dengan memperhatikan dampak terhadap lingkungan, pendidikan untuk membangun kepekaan terhadap potensi ekonomi dan inovasi untuk menciptakan lapangan pekerjaan baru bagi masyarakat.

Ketiga, lapangan pekerjaan di daerah tertinggal. Salah satu cara untuk mensukseskan pembangunan ekonomi adalah menurunkan angka pengangguran. ${ }^{22}$ Jika didefinisikan, pengangguran adalah keadaan seseorang yang sudah mampu bekerja dan termasuk ke dalam

${ }^{17}$ Novi Maryaningsih, Oki Hermansyah, and Myrnawati Savitri, "Pengaruh Infrastruktur Terhadap Pertumbuhan Ekonomi Indonesia," Buletin Ekonomi Moneter dan Perbankan 17, no. 1 (2014): 62-98. h. 67

${ }^{18}$ Muhammad Syahwalan, "Kebijakan Politik Keuangan Terhadap Pembangunan Negara Dalam Sistem Ketatanegaraan Islam,” Al-Imarah : Jurnal Pemerintahan dan Politik Islam 4, no. 1 (2019). h. 23

${ }^{19}$ Badan Pusat Statistik, "Indeks Pembangunan Manusia," Badan Pusat Statistik, last modified 2020, https://www.bps.go.id/brs.html. h. 11

${ }^{20}$ Putu Wulandari Tristananda, "Membumikan Education for Sustainable Development (Esd) Di Indonesia Dalam Menghadapi Isu - Isu Global," Jurnal Agama dan Budaya 2, no. 2 (2018): 42-49. h. 44

${ }^{21}$ Rachmatullah Rusli, "Klasifikasi Pendidikan Dalam Sudut Pandang Hadis Nabi," Jurnal Pendidikan Islam 8, no. 1 (2017): 49-66. h. 62

${ }^{22}$ Anton Trianto, "Elastisitas Penyerapan Tenaga Kerja Di Provinsi Sumatera Selatan," Akuisisi - Jurnal Akuntansi 13, no. 1 (2017): 15-38, https://fe.ummetro.ac.id/ejournal/index.php/JA/article/view/132. h. 15 
angkatan kerja namun belum memiliki pekerjaan. ${ }^{23}$ Jika melihat definisi demikian, pengangguran bukanlah angka yang mewakili semua umur di Indonesia dengan status tidak bekerja, namun hanya sebatas umur produktif yang tidak memiliki pekerjaan. Islam sebagai agama sangat menekankan seseorang untuk bekerja sesuai dengan kemampuannya. Tidak hanya menunggu tawaran pekerjaan, melainkkan juga mencari pekerjaan bahkan menciptakan lapangan pekerjaan. Allah berfirman dalam al-Qur'an surat al-Insyirah:5-7: "Karena sesungguhnya sesudah kesulitan itu ada kemudahan, sesungguhnya sesudah kesulitan itu ada kemudahan.Maka apabila kamu telah selesai (dari sesuatu urusan), kerjakanlah dengan sungguh-sungguh (urusan) yang lain." 24 Asbabun Nuzul ayat tersebut menurut Hasan alBasyri ra. ialah ayat turun berkenaan dengan kaum musyrik yang seringkali menghina kefakiran dan kemiskinan kaum muslim. ${ }^{25}$ Ayat 5 dan 6 surat tersebut merupakan anjuran untuk yakin bahwa di setiap kesusahan yang Allah berikan pada manusia pasti ada kemudahan di balik itu semua. ${ }^{26}$ Kemudahan adalah solusi bagi manusia agar dalam setiap urusan yang dianggap sulit, pasti Allah juga menyediakan jalan untuk menyelesaikan urusan tersebut. Ayat 7 pada surat tersebut merupakan perintah pada manusia agar berseungguhsungguh dalam bekerja. Selain itu, dalam menjalankan pekerjaan, kita tak boleh lupa untuk beribadah kepada Allah swt. ${ }^{27}$ Islam menekankan keseimbangan antara mencari penghidupan dunia dan bekal akhirat. Ketika manusia berurusan dengan masalah dunia (kerja) maka manusia dituntut untuk bekerja dengan keras, begitupun saat manusia meluangkan waktunya untuk beribadah kepada Allah, maka ia harus ikhlas dan tulus dalam beribadah.

Keempat, ketahanan pengan dan energi di daerah. Berbagai studi tentang pertumbuhan ekonomi menyebutkan bahwa pangan, energi dan air adalah faktor penting dalam membangun perekonomian. Pertama, Ravallion dan Datt merupakan ahli perkonomian yang menemukan bahwa pertumbuhan ekonomi di India pada tahun 2006 merupakan keberhasilan dalam pembangunan yang didukung oleh kekuatan pangan dengan meningkatkan kualitas pertanian. ${ }^{28}$ Mengutip dari Dartanto, Yohana dkk menjelaskan ketersediaan pangan selain berfungsi sebagai cadangan saat terjadi krisis, juga merupakan hasil bumi negara yang bisa diekspor untuk menambah cadangan devisa. Kedua, sumber daya energi merupakan salah satu indikator terpenting dalam membangun perekonomian negara. Namun, tidak semua energi yang dimiliki dapat diperbaharui, maka untuk mengantisipasi krisis dan punahnya energi tersebut, suatu negara dituntut untuk memiliki energi alternatif dan terbaharukan. Salah satu energi yang menjadi modal utama dalam memperbaiki pereknomian di Indonesia adalah bahan bakar minyak (BBM). Bahan bakar minyak sebagai energi non-produksi sudah tersedia sebagai sumber daya alam. Maka, negara sebagai pemegang hak paten atas kekayaan SDA tersebut memiliki fungsi pengolahan agar bisa disesuaikan dengan kebutuhan masyarakat. Selain fungsi pengolahan, negara juga berhak untuk menentukan harga energi karena dalam

\footnotetext{
${ }^{23}$ Tyas Ayu Prasanti, Triastuti Wuryandari, and Agus Rusgiyono, "Aplikasi Regresi Data Panel Untuk Pemodelan Tingkat Pengangguran Terbuka Kabupaten/Kota Di Provinsi Jawa Tengah," Jurnal Al Gaussian 4, no. 3 (2015): 687-696. h. 687

${ }^{24}$ RI, Al-Quran Dan Terjemahnya. h. 1284

${ }^{25}$ Ahmad Hatta, Tafsir Qur'an Perkata Dilengkapi Dengan Asbabun Nuzul Dan Terjemahan (Jakarta: Maghfirah Pustaka, 2012). h. 89

${ }^{26}$ M. Quraish Shihab, Tafsir Al-Misbah (Jakarta: lentera hati, 2002). h. 416-417

${ }^{27}$ Ibn Kasir, Tafsir Ibn Kasir, terj. Abdu. (Bogor: Pustaka Imam Syafi'I, 2010). h. 499

${ }^{28}$ Tulus Tahi HT, Pembangunan Ekonomi Dan Utang Luar Negeri (Jakarta: Raja Grafindo Persada, 2012). h. 173
} 
menentukan harga, energi tidak melaui mekanisme pasar. ${ }^{29}$ Ketiga, sumber daya air merupakan kekayaan negara yang digunakan untuk menunjang keberlangsungan hidup masyarakat. Selain fungsinya untuk diminum, air juga memiliki peran penting dalam membangun sektor pertanian melalui saluran irigasi. Allah berfirman dalam al-Qur'an surat al-Baqarah: 164: "Sesungguhnya dalam penciptaan langit dan bumi, silih bergantinya malam dan siang, bahtera yang berlayar di laut membawa apa yang berguna bagi manusia, dan apa yang Allah turunkan dari langit berupa air, lalu dengan air itu Dia hidupkan bumi sesudah mati (kering)-nya dan Dia sebarkan di bumi itu segala jenis hewan, dan pengisaran angin dan awan yang dikendalikan antara langit dan bumi; sungguh (terdapat) tanda-tanda (keesaan dan kebesaran Allah) bagi kaum yang memikirkan." 30 Asbabun Nuzul ayat tersebut menurut sebagai mana hadis Nabi yang diriwayatkan Atha' ra. adalah sebagai respon atas pernyataan kafir Quraisy Makkah mengatakan pada Nabi: bagaimana mungkin Tuhan yang satu bisa mencukupi seluruh umat manusia?" maka turunlah ayat ini kepada Nabi Muhammad saw. ${ }^{31}$ Air sebagai karunia Allah sangat penting fungsinya. Sebagai amanah yang dititipkan pada manusia, hendaknya dalam memanfaatkan sumber daya tersebut selalu mengepankan keefesienan. Program konservasi air yang dijalankan oleh pemerintah bertujuan untuk merehabilitasi, menjaga, memelihara dan memanfaatkannya sesuai dengan kebutuhan. ${ }^{32}$ Meski ketersediaan air di Indonesia sangat memadai dibandingkan negara-negara Timur Tengah, bukan berarti kita bisa menggunakan air secara berlebihan. Indonesia sebagai negara tropis dengan dua musim memiliki kemungkinan terjadinya banjir pada musim hujan. Pada saat inilah, cadangan air bersih sangat penting ketersediannya untuk dimanfaatkan. Sebaliknya, pada musim kemarau yang berlangsung hingga beberapa bulan, cadangan baik di bendungan, waduk, dan danau buatan bisa digunakan sebagai pengairan. Kesenjangan sosial terjadi di daerah yang sebenarnya memiliki sumber daya alam melimpah. Untuk membangun daerah tersebut sebetulnya sudah hanya memerlukan sumber daya manusia yang mumpuni, infrastrukur yang memadai, dan dukungan invsetasi baik dari dalam maupun luar negeri. Yang terpenting dari itu semuanya ialah pemberdayaan masyarakat agar diikutsertakan dalam proses pembanguan.

\section{Ekonomi Islam dan Keadilan Sosial}

Pembangunan merupakan hal yang perlu dilakukan untuk memperbaiki taraf hidup masyarakat. Pembangunan dalam Islam harus mengutamakan prinsip-prinsip keadilan dan tidak mengandung unsur diskriminatif terhadap salah satu kelompok masyarakat. Perekonomian merupakan bagian yang tidak dapat dipisahkan dari kehidupan masyarakat Islam, untuk itu perlu prinsip-prinsip yang menjadi landasan setiap tingkah laku ekonomi umat Islam itu sendiri.

Ekonomi Islam adalah sistem perekonomian moderat, tidak mengacu pada sistem komunis dan sistem liberal. Ekonomi Islam merupakan sistem perekonomian yang mengacu pada al-Qur'an dan Hadits, tujuannya agar kehidupan manusia tidak hanya mementingkan

${ }^{29}$ Yohana Paramita, Ainur Rosidah, and Mei Suryanti, "Potensi Subsidi Energi Dalam Mengurangi Kemiskinan," Jurnal Humaniora 4, no. April (2020): 74-87. h. 5-6

${ }^{30} \mathrm{RI}$, Al-Quran Dan Terjemahnya. h. 48

${ }^{31}$ Hatta, Tafsir Qur'an Perkata Dilengkapi Dengan Asbabun Nuzul Dan Terjemahan. h. 25

${ }^{32}$ M. Kudeng Sallata, "Konservasi Dan Pengelolaan Sumber Daya Air Berdasarkan Keberadaannya Sebagai Sumber Daya Alam," Info Teknis EBONI 12, no. 1 (2015): 75-86, http://balithutmakassar.org/wpcontent/uploads/2014/11/7_Konservasi-Air-berdasarkan-SDA_Info-Teknis-Eboni-Vol-12-No-1-2015.pdf. h. 7677 
kesejahteraan yang bersifat dunia saja, melainkan juga memperhatikan kesejahteraan di akhirat.

Untuk menjamin terciptanya keadian sosial di masyarakat, ekonomi Islam memiliki nilainilai yang menjadi koridor baik dalam proses pembangunan, transaksi, maupun invsetasi. ${ }^{33}$ Pertama, kepemilikan manusia terhadap harta adalah kepemilikan yang tidak mutlak. Islam mengakui bahwa kepemilikan segala yang ada di langit dan di bumi sebagai kekayaan Allah. Untuk itu, sumber daya alam yang dimanfaatkan oleh pemerintah hendaknya digunakan sebagai bekal ibadah, membangun kesejahteraan semua elemen masyarakat, dan tidak menguntungkan satu pihak.

Prinsip kepemilikan atau yang dikenal dengan istilah multi-faceted yaitu kepemilikan segala yang ada di langit dan di bumi sebagai kekayaan Allah. Sebagai negara hukum, kepemilikan tersebut kemudian diklaim oleh negara dengan tujuan mensejahterakan masyarakat. Prinsip ini menolak segala bentuk klaim inividu terhadap suatu sumber daya alam. Untuk itu, negara memanfaatkan alam sebagai tanggung jawab kepada Allah dan menggunakannya berdasarkan prinsip keadilan. ${ }^{34}$

Kedua, dalam memanfaatkan sumber daya alam, manusia dituntut untuk berlaku seimbang. Menusia dilarang untuk mengeksploitasi sumber daya alam secara terus menerus tanpa adanya pembaharuan. Dalam Islam, sifat boros adalah hal yang diharamkan. Memanfaatkan sumber daya alam harus secara efisien, efektif, memiliki manfaat yang nyata, dan berorientasi pada pemenuhan semua generasi.

Prinsip keseimbangan harus beriringan dengan prinsi keadilan sosial. Prinsip keadilan sosial merupakan prinsip yang paling penting dalam konsep ekonomi Islam. Tiga dimensi pembangunan berkelanjutan yaitu memenuhi kriteria ekonomi, bermanfaat secara sosial, dan menjaga kelestarian lingkungan hidup. Ketiga aspek tersebut harus berjalan beriringan dan diperuntukkan dalam membangun masyarakat yang sejahtera. ${ }^{35}$

Ketiga, memanfaatkan kekayaan alam sebagai karunia Allah harus didasari dengan sikap adil dan merata. Pembangunan berkelanjutan tidak boleh terfokus pada satu daerah, melainkan semua daerah yang memiliki hak atas kekayaan alam sesuai prinsip-prinsip kepemilikan. Selain itu, Islam juga memiliki nilai instrumental dalam membangun perkonomian, meliputi larangan riba, zakat, kerjasama, dan jaminan sosial. Jika nilai-nilai instrumental tersebut dilaksanakan, maka akan terwujud sistem ekonomi yang menguntungkan, seimbang, dan mensejahterakan semua pihak.

Prinsip tersebut memberi peluang kepada pemerintah dan masyarakat untuk mengembangkan sumber daya alam menjadi lapangan pekerjaan. Setiap individu berhak untuk memanfaatkan kekayaan alam selama tidak bertetangan dengan hukum agama dan hukum negara. Maoododi menjelaskan bahwa untuk mencapai keberhasilan dalam pembangunan, perlu adanya keharmonisan dan kolaborasi antara aspek spiritual dan aspek material. $^{36}$

\footnotetext{
${ }^{33}$ Nurul Huda, Ekonomi Makro Islam (Jakarta: Kencana, 2018). h. 4

${ }^{34}$ KA Koerniawan, "Prinsip-Prinsip Dasar Ekonomi Islam Dan Pengaruh Terhadap Penetapan Standar Akuntansi," Jurnal Ekonomi Modernisasi $\quad 8, \quad$ no. $\quad 1 \quad$ (2012): http://ejournal.unikama.ac.id/index.php/JEKO/article/view/208. h. 81

${ }^{35}$ Imam Mukhlis, "Eksternalitas, Pertumbuhan Ekonomi Dan Pembangunan Berkelanjutan Dalam Perspektif Teoritis," Jurnal Ekonomi Bisnis 14, no. 3 (2009): 1-9, http://fe.um.ac.id/wpcontent/uploads/2010/01/imam-mukhlis_2.pdf. h. 191-199

${ }^{36}$ Abul Ala Maududi, Masalah Ekonomi Manusia (Pakistan: Lahore, 2012). h. 88
} 


\section{Simpulan}

Untuk menekan angka kesenjangan antara satu daerah dengan daerah lain seharusnya pemerintah dalam melakukan pembangunan berkelanjutan berpegang pada tiga prinsip utama ekonomi Islam yaitu kepemilikan hanya milik Allah, kebebasan untuk bersaing dan memperkaya diri sendiri, dan keseimbangan antara pemanfaatan dan pembaharuan sumber daya alam. Ketiga prinsip tersebut diimplementasikan dan dikolaborasikan dengan upayaupaya strategis meliputi perbaikan mutu pendidikan di daerah tertinggal, membangun konektifitas infrastruktur, penyediaan lapangan kerja, dan upaya untuk menjaga ketahanan pangan dan energi.

Dalam Islam, pemanfaatan sumber daya alam didasarkan pada prinsip efesiensi, efektifitas dan pembaharuan. Itu artinya, pemerintah dan masyarakat bisa saja memanfaatkan sumber daya alam yang ada namun harus melakukan tindakan-tindakan pembaharuan, konservatif, dan mencari sumber daya alternatif. Islam melarang ekspolitasi yang berlebihan, di sisi lain Islam juga tidak memperkenankan sumber daya alam yang ada terbengkalai tanpa pemanfaatan. Untuk itu, ekonomi Islam berprinsip pada sistem ekonomi moderat antara pemanfaatan dan pembaharuan.

\section{Daftar Pustaka}

Ali, Zainuddin. Metodologi Penelitian Hukum. Jakarta: Sinar Grafika, 2011.

BPS. Proyeksi Penduduk Indonesia 2010-2035. Bulletin of Experimental Biology and Medicine. Vol. 90. Jakarta: Bada Pusat Statistik, 2013.

Churiyah, Madziatul. Mengenal Ekonomi Islam. Surabaya: Surya Pena Publishing, 2014.

Fauzi, Akhmad, and Alex Oxtavianus. "The Measurement of Sustainable Development in Indonesia." Jurnal Ekonomi Pembangunan: Kajian Masalah Ekonomi dan Pembangunan 15, no. 1 (2014): 68.

Fauzia, Ika Yuni, and Abdul Kadir Riyadi. Prinsip-Prinsip Dasar Ekonomi Islam. Jakarta: Kencana, 2014.

Hatta, Ahmad. Tafsir Qur'an Perkata Dilengkapi Dengan Asbabun Nuzul Dan Terjemahan. Jakarta: Maghfirah Pustaka, 2012.

HT, Tulus Tahi. Pembangunan Ekonomi Dan Utang Luar Negeri. Jakarta: Raja Grafindo Persada, 2012.

Huda, Nurul. Ekonomi Makro Islam. Jakarta: Kencana, 2018.

Husnul, Habib Muhammad, Raden Rustam Hidayat, and Sri Sulasmiyati. “Analisis Pengaruh Inflasi, Kurs (IDR/USD), Produk Domestik Bruto Dan Harga Emas Dunia Terhadap Indeks Harga Saham Gabungan.” Jurnal Administrasi Bisnis 53, no. 1 (2017): 66-74. http://administrasibisnis.studentjournal.ub.ac.id/index.php/jab/article/view/2183.

Kasir, Ibn. Tafsir Ibn Kasir. Terj. Abdu. Bogor: Pustaka Imam Syafi' I, 2010.

Koerniawan, KA. "Prinsip-Prinsip Dasar Ekonomi Islam Dan Pengaruh Terhadap Penetapan Standar Akuntansi." Jurnal Ekonomi Modernisasi 8, no. 1 (2012): 78-89. http://ejournal.unikama.ac.id/index.php/JEKO/article/view/208.

Listiawati, Nur. "Pelaksanaan Pendidikan Untuk Pembangunan Berkelanjutan Oleh Beberapa Lembaga." Jurnal Pendidikan dan Kebudayaan 19, no. 3 (2013): 430.

Maryaningsih, Novi, Oki Hermansyah, and Myrnawati Savitri. "Pengaruh Infrastruktur Terhadap Pertumbuhan Ekonomi Indonesia." Buletin Ekonomi Moneter dan 
Perbankan 17, no. 1 (2014): 62-98.

Maududi, Abul Ala. Masalah Ekonomi Manusia. Pakistan: Lahore, 2012.

Mukhlis, Imam. "Eksternalitas, Pertumbuhan Ekonomi Dan Pembangunan Berkelanjutan Dalam Perspektif Teoritis." Jurnal Ekonomi Bisnis 14, no. 3 (2009): 1-9. http://fe.um.ac.id/wp-content/uploads/2010/01/imam-mukhlis_2.pdf.

Niken Pratiwi, Dwi Budi Santosa, Khusnul Ashar. "Analisis Implementasi Pembangunan Berkelanjutan Di Jawa Timur.” Jiep 18, no. 1 (2018): 1-16.

Paramita, Yohana, Ainur Rosidah, and Mei Suryanti. "Potensi Subsidi Energi Dalam Mengurangi Kemiskinan.” Jurnal Humaniora 4, no. April (2020): 74-87.

Prasanti, Tyas Ayu, Triastuti Wuryandari, and Agus Rusgiyono. "Aplikasi Regresi Data Panel Untuk Pemodelan Tingkat Pengangguran Terbuka Kabupaten/Kota Di Provinsi Jawa Tengah.” Jurnal Al Gaussian 4, no. 3 (2015): 687-696.

Purwana, Agung Eko. "Pembangunan Nasional Dalam Perspektif Ekonomi Islam." Justitia Islamica 10, no. 1 (2013).

Rahadian, A.H. "Strategi Pembangunan Berkelanjutan." Prosiding Seminar STIAMI III, no. 01 (2016): 46-56. file:///C:/Users/USER/Downloads/strategi-pembangunanberkelanjutan (1).pdf.

Rahardjo, M.Dawam. Islam Dan Tansformasi Sosial Ekonomi. Jakarta: LSAF, 2012.

RI, Departemen Agama. Al-Quran Dan Terjemahnya. Jakarta: Gema Insani press, 2003.

Rosana, Mira. "Kebijakan Pembangunan Berkelanjutan Yang Berwawasan Lingkungan Di Indonesia.” KELOLA Jurnal Ilmu Sosial 1, no. 1 (2018): 148-163.

Rusli, Rachmatullah. "Klasifikasi Pendidikan Dalam Sudut Pandang Hadis Nabi." Jurnal Pendidikan Islam 8, no. 1 (2017): 49-66.

Sallata, M. Kudeng. "Konservasi Dan Pengelolaan Sumber Daya Air Berdasarkan Keberadaannya Sebagai Sumber Daya Alam.” Info Teknis EBONI 12, no. 1 (2015): 75-86. http://balithutmakassar.org/wp-content/uploads/2014/11/7_Konservasi-Airberdasarkan-SDA_Info-Teknis-Eboni-Vol-12-No-1-2015.pdf.

Shihab, M. Quraish. Tafsir Al-Misbah. Jakarta: lentera hati, 2002.

Statistik, Badan Pusat. "Indeks Pembangunan Manusia." Badan Pusat Statistik. Last modified 2020. https://www.bps.go.id/brs.html.

Sukirno, Sadono. Makroekonomi Teori Pengantar. Jakarta: Raja Grafindo Persada, 2015.

Syahwalan, Muhammad. "Kebijakan Politik Keuangan Terhadap Pembangunan Negara Dalam Sistem Ketatanegaraan Islam." Al-Imarah : Jurnal Pemerintahan dan Politik Islam 4, no. 1 (2019).

Trianto, Anton. "Elastisitas Penyerapan Tenaga Kerja Di Provinsi Sumatera Selatan." Akuisisi - Jurnal Akuntansi 13, no. 1 (2017): 15-38. https://fe.ummetro.ac.id/ejournal/index.php/JA/article/view/132.

Tristananda, Putu Wulandari. "Membumikan Education for Sustainable Development (Esd) Di Indonesia Dalam Menghadapi Isu - Isu Global.” Jurnal Agama dan Budaya 2, no. 2 (2018): 42-49.

Zulfi Suhendra. "HIPMI Sebut 1\% Orang Kaya RI Kuasai 50\% Kekayaan Nasional." DetikFinance. Last modified 2018. Accessed June 19, 2020. https://finance.detik.com/berita-ekonomi-bisnis/d-4056625/hipmi-sebut-1-orangkaya-ri-kuasai-50-kekayaan-nasional?_ga=2.175454443.837156960.1576976882- 
430614702.1562817330. 